\title{
E-Learning in Web 3.0
}

\author{
Maria Dominic \\ Department of Computer Science, Sacred Heart College, India \\ Email: dominic@shctpt.edu
}

Sagayaraj Francis

Department of Computer Science and Engineering, Pondicherry Engineering College, India

Email: fsfrancis@pec.edu

Anthony Pilomenraj

Department of MCA, Sacred Heart College, India

Email: philomen@ shctpt.edu

\begin{abstract}
Web 2.0 is about social networking and collaboration between the creator and the user. Web 3.0 is termed as intelligent web or semantic web with technologies like big data, linked data, cloud computing, $3 \mathrm{D}$ visualization, augmented reality and more to make passive learner into active learner in the learning process. This paper identifies the characteristics of the different generations of web and its effect on the different generations of e-learning and also identifies the various issues related with web 3.0. Finally a study is made on the user preferences and recorded in this paper.
\end{abstract}

Index Terms-Learning Styles, e-Learning 3.0, Web 3.0, Web 4.0, Collaborative learning.

\section{INTRODUCTION}

\section{A. Learning}

Learning is a two phase process that involves reception and processing of the information received. Reception engages the various senses to gather information from external sources, whereas the internal activities of memorization, induction, deduction, introspection, reflection are primarily necessary in the processing activity. [1]. Every learner has a preferred way of reception and process the information. This activity is known as a learning style. According to FelderSilverman [2] there are 32 different styles of learning.

Once a teacher becomes aware of these learning styles he will become more sensitive in designing classroom activities that enhances the teaching-learning process. Numerous learning styles theories are proposed by various theorists and have classified them based on characteristics of learning. Synthesis of learning style theories are tabulated in Table 1. Felder-Silverman classified the learning characteristics as the following.

\section{B. Active}

Active learners always learn by action, through physical activity or by discussion to try, test, analyze and prefer to work in a group/team.

\section{Reflective}

Reflective learners are deep thinkers. Basically they think over their observation by introspection and prefer to work individually or in pairs.

\section{Visual}

Visual aids such as pictures, diagrams, graphs, flowcharts, videos, demonstrations enhance the visual learning. Most of the learners feel that visual learning is the best way to learn easily and effectively.

\section{E. Verbal}

Auditory learners often talk to themselves. They also move their lips and read out loud. They often do better talking to a colleague.

\section{F. Sensing}

The other physical sensations [4] like touch, smell, taste primarily involve in the act of sensing. This method is the prime method in the field of physical and chemical sciences and catering.

\section{G. Intuitive}

Intuitive learners tend to focus more on the world of possibility. They are basically Theoretical, intellectual, and knowledge oriented. Intuitive thinkers prefer to be challenged intellectually and to think things through for themselves. They are curious about ideas. Unlike the sensing learners, the intuitive learners [4] use indirect perception such as speculation an, imagination to unravel the mystery behind the truth.

\section{H. Sequences}

Sequence learning is a step by step learning. This method provides information in an incremental way to the learner, encouraging him to take a step forward in linear way. Such kind of learners will be strong in convergent thinking and analysis. 


\section{Global}

Global learner [5] learn in large jumps, leap. They may find it difficult to explain how they reached the solution. It is just the opposite of sequence learners they are good in divergent thinking and synthesis.

This paper is structured as follows. Section II describes about e-learning and lists some of the popular learning styles. Section III identifies the web characteristics from web1.0 to web 4.0. Section IV shows the analysis of the attributes that determines the factors for application development in web 3.0. Finally a brief conclusion is described in section $\mathrm{V}$.

\section{E-LEARNING}

Education is defined as a conscious attempt to promote learning to others to acquire knowledge, skills and character. To achieve this mission, different pedagogies were used. Later, the advent of new information and communication technologies and internet make the teaching and learning process simple and extend to the birth of e-learning. The e-learning enables the learner to set up his own phase of learning. Breaking the limitation of geographical barriers, it promotes individual learning [5]. The e-learning is nothing but, the extensive use of internet, electronic devices and network to disseminate knowledge. The key factors of e-learning are reusing, sharing resources and interoperability. At present, various organizations provide e-learning tools with multiple functionalities. MOODLE (Modular Object Oriented Dynamic Learning Environment) is one among them which would support the e- learners. This in turn created difficulty in sharing the learning objects between heterogeneous sites, and standards such as SCORM \& SCORM LOM [6], IMS \& IMS DRI [7], AICC [8] and likewise were proposed by different organizations to overcome this difficulty.

\section{EVOLUTION OF WEB AND E-LEARNING}

\section{A. Web 1.0, e-Learning 1.0 (Link to anything)}

The internet was invented by Tim Berners-Lee in 1989, with the vision of communicating or sharing information in a common information space, called web. [9]. By the exponential growth, it became a platform to store and access various versions of learning contents such as text, pictures, audio and video. The main drawback of web 1.0 is the creation of the content and sharing with others. The users are unable to curate knowledge. As a result the web 1.0 is vividly recognized as read only web with its general attributes like static information and minimal interaction between web sites. Beside this, e-learning 1.0 evolved along with web 1.0 with many Learning management systems (LMS) like copying the various aspects of traditional learning with databases, communication tools and task solutions. Finally, the Web 1.0 allows to incorporate the learning theories of instructivism, behaviorism and cognitivist.

Table 1. LEARNING STYLES [3]

\begin{tabular}{|c|c|c|c|c|c|}
\hline & \multicolumn{5}{|c|}{ Characteristic's } \\
\hline 1 & Accommodating & Diverging & Converging & \multicolumn{2}{|c|}{ Assimilating } \\
\hline 2 & Activists & Reflectors & Theorists & \multicolumn{2}{|c|}{ Pragmatists } \\
\hline 3 & Environmental & Emotional & Sociological & Physiological & Psychological \\
\hline 4 & Active / Reflective & Visual / Verbal & Sensing / Intuitive & \multicolumn{2}{|c|}{ Sequential / Global } \\
\hline 5 & Visual & Auditory & \multicolumn{3}{|c|}{ Kinesthetic } \\
\hline
\end{tabular}




\section{B. Web 2.0, e-Learning 2.0 (User Participation)}

As stated in Wikipedia, web 2.0 is a transition from web sites. Added to that, it is a full computing platform, replacing desktop applications with web applications, with attributes like network as platform, continuous updated software, consuming and remixing data from various sources [11]. "Digital Natives" were able to curate content and it demands the learner to participate actively in the learning process. Web 2.0 is entirely learner centric reality; therefore, teaching and learning process became less separated. It allows to use the other learning theories like constructivism and Social Constructionism. Figure 1 depicts the evolution of the web and Table 2 tabulates the characteristics of different generations of web.

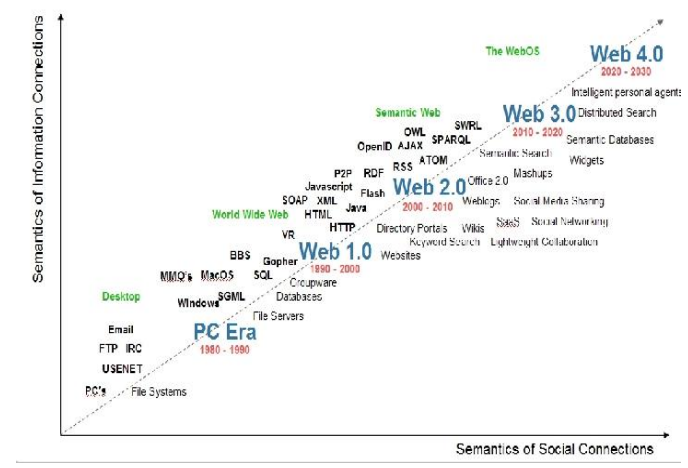

Fig 1. EVOLUTION OF WEB [10]

Web 3.0, e-Learning 3.0 (Existing Data Reconnected)

The predictions of web 3.0 vary due to the difference in the technologies which will make up web 3.0. Web 3.0 is still in its formative years but the early indicators indicate that it will include the technologies depicted in Figure 2. E-Learning has been evolving along the side of world wide web. E-learning 1.0 was all about providing information to users, e-learning 2.0 was about providing information, authoring the contents and interaction capabilities. E-learning 3.0 had the capabilities of elearning 1.0, 2.0 and rich 3D virtual learning environment. The table 3 illustrates the relationships between the generations of e-learning. It remains as a hypothesis how these technologies may be utilized in elearning 3.0.

Table 2 CHARACTERISTICS OF WEB 1.0, WEB 2.0 AND WEB 3.0

\begin{tabular}{|l|l|l|}
\hline Web 1.0 & Web 2.0 & Web 3.0 \\
\hline Read & $\begin{array}{l}\text { Read and } \\
\text { Write }\end{array}$ & $\begin{array}{l}\text { Read, Write and } \\
\text { Execute }\end{array}$ \\
\hline Client Server & Peer to Peer & $\begin{array}{l}\text { Portable } \\
\text { Personal Web }\end{array}$ \\
\hline $\begin{array}{l}\text { HTML, } \\
\text { Portals }\end{array}$ & XML, RSS & RDF \\
\hline $\begin{array}{l}\text { Companies } \\
\text { Own }\end{array}$ & $\begin{array}{l}\text { Communities } \\
\text { Share }\end{array}$ & Individuals \\
\hline Web Pages & $\begin{array}{l}\text { Web } \\
\text { Applications }\end{array}$ & $\begin{array}{l}\text { Semantic } \\
\text { Applications }\end{array}$ \\
\hline
\end{tabular}

Artificial Intelligence
Most of the success of AI are mainly in the closed domains, where rules and objectives are well defined but limited in open domains like education where there is large set of data and require significant computing power. But, now the invention of cloud solved the problem of storing huge amount of data, establish links between datasets by linked data and to perform computation.

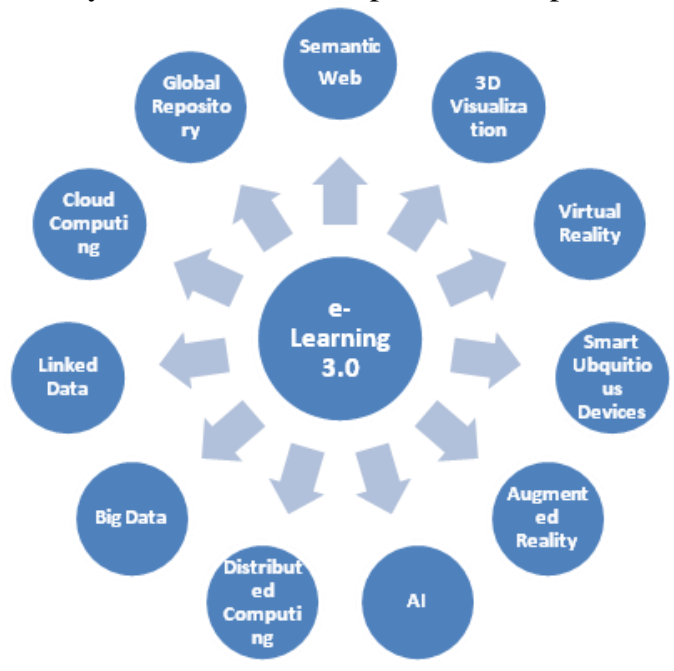

Fig 2. TECHNOLOGIES IN E-LEARNING 3.0

\section{Big Data}

The web 2.0 technologies like wikis, blog, tweets generate vast amount of data, yet, they are all underutilized. Therefore, AI became a perfect tool to extract the patterns in the vast amount of data and its utilization.

\section{Linked Data}

The data generated by web2.0 is in free-form and with different characteristics. Hence, they could not be linked, processed and utilized. Linked data framed by BernersLee is a set of practices for publishing and connecting datasets on web. The linked data principles are listed in [12].

\section{E. Cloud Computing}

Significant amount of infrastructure is necessarily required to process and analyze large set of data produced by web. To perform this process cloud computing services can be utilized without much burdening the exchequer.

\section{F. 3D Visualization}

$3 \mathrm{D}$ visualization and interaction enrich the learning, by making a whole range of tasks easier including fine motor skill interaction, exploration of virtual spaces and manipulation of virtual objects.

\section{G. Augmented Reality and Virtual Reality}

Augment reality is a live, direct or indirect view of a real world which is been augmented by computer [13]. Augmented reality technologies recognize what the user is doing and tries to enhance it. This technology 
enhances ones perception on reality whereas the virtual reality substitutes the real world with a simulated one.

\section{H. Semantic Web}

Semantic web was introduced as an extension to the WWW to allow machines to search and process web contents, based on their meanings and find relationships between them using inference rules and organizational tools. Hitzler et al. identifies that semantic web can be used to

1. Describe knowledge - Semantic web adds machine understandable form of data about the documents and how they are related. It is done using Resource Description Framework (RDF), RDF Schema (RDFS), Web Ontology Language (OWL), query language for RDF (SPARQL), SKOS (Simple Knowledge Organization System).

2. Reason out meaningful conclusions.

3. Exchanging information is done with TCP/IP protocols and file formats like RSS.

\section{Distributed Computing}

In distributed computing, a task can be tackled by various computers. In it each computer performs its own assigned task. Scientists believe that the web will become a giant brain, able to think by distributing, analyzing and extrapolating [15].

\section{J. Hand held and Wearable Devices}

E-learning was revolutionized by performing teaching learning process of anywhere, anytime, anything by means of hand held and wearable devices. Some of the devices can be PDA, smart phones, tablets, hand held, hand/leg worn, head worn etc. These devices are miniature electronic devices worn by the learner which are connectable, accessible, flexible, wireless performing ubiquitous computing [16]. Wearable devices are also applied in sensory integration, behavioral modeling, health care, service management, electronic textiles [17].

\section{K. $\quad$ Challenges in Web 3.0, e-learning 3.0}

The first major challenge is due to the nature of web 3.0 its vastness, interoperability, lack of server side checks, less privileges control and increased privacy and security risk [18]. The second major issue is whether the current education scenario is ready to utilize the benefits of web 3.0 when they are still struggling with the previous generations [19].

Table 3. RELATIONSHIP BETWEEN GENERATIONS OF E-LEARNING

\begin{tabular}{|l|l|l|}
\hline Version & Concept & Technologies \\
\hline 1 & $\begin{array}{l}\text { Content Management } \\
\text { Read or Write Only }\end{array}$ & $\begin{array}{l}\text { CBT, Learning Management Systems, } \\
\text { eBooks, Virtual Learning Environment }\end{array}$ \\
\hline 2 & $\begin{array}{l}\text { Read and Write Blended Learning, Content } \\
\text { Authoring, Collaborate, Multimedia } \\
\text { Content }\end{array}$ & $\begin{array}{l}\text { LCMS, Social Networks, Audio/ Video } \\
\text { Conference Social, Mashups }\end{array}$ \\
\hline 3 & $\begin{array}{l}\text { Learner-Centeric, U-learning, Knowledge } \\
\text { representation }\end{array}$ & $\begin{array}{l}\text { PLEs, Mashups Social, Semantic Web, } \\
\text { Personal Agents, Big Data, Linked Data, 3D, } \\
\text { Global Database }\end{array}$ \\
\hline
\end{tabular}

\section{Web 4.0 (Read/Write/Execute/Concurrency)}

It is still in its infancy, there is no concrete definition on its appearance and its operations. It is named as symbiotic web in which human mind can interact with the machine in symbiosis. Even though there is no idea on technologies in web 4.0 it is sure that AI would play a greater role in making the web, which would interact with the humans in a high intelligent way [20, 21].

\section{ANALYSIS OF THE ATTRIBUTES IN WEB 3.0}

Attributes identify the way an application in web 3.0 will be. The attributes considered are the preferences of the learner and they are 3D, augmented reality or virtual reality, ubiquitous and wearable devices, audio/video/text, related files/sites intelligently filtered. Data was collected on these attributes using a questionnaire with closed type of questions from 100 graduate and post graduate students in our campus. The analysis of these attributes determines the factors for application development in web 3.0. The sample questionnaire is tabulated in Table IV. The frequency statistics for questions in the questionnaire are tabulated in Table V, Table VI, Table VII, Table VIII, Table IX, Table X and Table XI. The Correlation between the different variables in the questionnaire is tabulated in Table XI. 
Table 4. SAMPLE QUESTIONNAIRE

\begin{tabular}{|l|l|l|}
\hline S.No & Question Type & Response Type \\
\hline 1 & Do you prefer a 3D Tutor? & Yes/No \\
\hline 2 & Are you sensitive to the gender of the 3D Tutor? & Yes/No \\
\hline & $\begin{array}{r}\text { Do you prefer the learning objects to incorporate } \\
\text { a) 3D Visuals } \\
\text { b) Virtual Reality } \\
\text { c) Augmented Reality } \\
\text { d) Text } \\
\text { e) All of the Above }\end{array}$ & a/b/c/d \\
\hline 3 & $\begin{array}{l}\text { Preferred way to communicate with the Tutor } \\
\text { a) Lap Top } \\
\text { b) Ubiquitous Devices } \\
\text { c) Wearable Devices }\end{array}$ & \\
\hline 4 & $\begin{array}{r}\text { Your preferred way of communicating with the Tutor } \\
\text { a) Text } \\
\text { b) Voice }\end{array}$ & a/b/c \\
\hline 5 & $\begin{array}{l}\text { Aggregation of the Web Resources can be done by } \\
\text { I. Tutor } \\
\text { II. Yourself }\end{array}$ & a/b \\
\hline 6 & $\begin{array}{l}\text { Do you Prefer } \\
\text { a) Sequential Learning Path } \\
\text { b) Personalized Learning Path }\end{array}$ & $\mathrm{a} / \mathrm{b}$ \\
\hline 7 & $\begin{array}{l}\text { You preferred way of communicating with the Tutor } \\
\text { a) Any point of time (Random) } \\
\text { b) Only at the end }\end{array}$ & $\mathrm{a} / \mathrm{b}$ \\
\hline
\end{tabular}

Table 5. PREFERENCE FOR A 3D TUTOR

\begin{tabular}{|l|l|l|}
\hline & Frequency & Percent \\
\hline Yes & 86 & 86.0 \\
\hline No & 14 & 14.0 \\
\hline Total & 100 & 100.0 \\
\hline
\end{tabular}

Table 6. GENDER SENSITIVITY TO THE 3D TUTOR

\begin{tabular}{|l|l|l|}
\hline & Frequency & Percent \\
\hline Yes & 55 & 55.0 \\
\hline No & 45 & 45.0 \\
\hline Total & 100 & 100.0 \\
\hline
\end{tabular}

Table 7. PREFERRED LEARNING OBJECTS

\begin{tabular}{|l|l|l|}
\hline & Frequency & Percent \\
\hline 3D Visuals & 28 & 28.0 \\
\hline Virtual Reality & 30 & 30.0 \\
\hline Augmented Reality & 18 & 18.0 \\
\hline Text & 24 & 24.0 \\
\hline Total & 100 & 100.0 \\
\hline
\end{tabular}

Table 8. COMMUNICATION DEVICES

\begin{tabular}{|l|l|l|}
\hline & Frequency & Percent \\
\hline Lap Top & 42 & 42.0 \\
\hline Ubiquitous Devices & 9 & 9.0 \\
\hline Wearable Devices & 10 & 10.0 \\
\hline All of the Above & 39 & 39.0 \\
\hline Total & 100 & 100.0 \\
\hline
\end{tabular}

Table 9. MEANS OF COMMUNICATING WITH THE TUTOR

\begin{tabular}{|l|l|l|}
\hline & Frequency & Percent \\
\hline Text & 16 & 16.0 \\
\hline Voice & 31 & 31.0 \\
\hline All of the Above & 53 & 53.0 \\
\hline Total & 100 & 100.0 \\
\hline
\end{tabular}

Table 10. POINT OF COMMUNICATION WITH THE TUTOR

\begin{tabular}{|l|l|l|}
\hline & Frequency & Percent \\
\hline $\begin{array}{l}\text { Any point of time } \\
\text { (Random) }\end{array}$ & 60 & 60.0 \\
\hline Only at the end & 40 & 40.0 \\
\hline Total & 100 & 100.0 \\
\hline
\end{tabular}


Table 11. AGGREGATION OF THE WEB RESOURCES

\begin{tabular}{|l|l|l|}
\hline & Frequency & Percent \\
\hline Tutor & 19 & 19.0 \\
\hline Yourself & 34 & 34.0 \\
\hline All of the Above & 47 & 47.0 \\
\hline Total & 100 & 100.0 \\
\hline
\end{tabular}

Table 12. PREFERRED LEARNING PATH

\begin{tabular}{|l|l|l|}
\hline & Frequency & Percent \\
\hline $\begin{array}{l}\text { Sequential Learning } \\
\text { Path }\end{array}$ & 55 & 55.0 \\
\hline $\begin{array}{l}\text { Personalized Learning } \\
\text { Path }\end{array}$ & 45 & 45.0 \\
\hline Total & 100 & 100.0 \\
\hline
\end{tabular}

Table 13. CORRELATIONS

\begin{tabular}{|c|c|c|c|c|c|c|c|c|}
\hline & 1 & 2 & 3 & 4 & 5 & 6 & 7 & 8 \\
\hline 1 & 1 & & & & & & & \\
\hline 2 & -.017 & 1 & & & & & & \\
\hline 3 & -.085 & .087 & 1 & & & & & \\
\hline 4 & -.178 & $\begin{array}{l}.254 \\
(*)\end{array}$ & $\begin{array}{l}.444 \\
(* *)\end{array}$ & 1 & & & & \\
\hline 5 & $\begin{array}{l}-.239 \\
(*)\end{array}$ & $\begin{array}{l}.280 \\
(* *)\end{array}$ & $\begin{array}{l}.225 \\
(*)\end{array}$ & $\begin{array}{l}.433 \\
(* *)\end{array}$ & 1 & & & \\
\hline 6 & .041 & $\begin{array}{l}.221 \\
(*) \\
\end{array}$ & .085 & $\begin{array}{r}.289 \\
(* *) \\
\end{array}$ & .188 & 1 & & \\
\hline 7 & -.017 & .192 & .069 & .063 & .091 & -69 & 1 & \\
\hline 8 & .141 & .041 & .141 & .009 & -.077 & .128 & .000 & 1 \\
\hline
\end{tabular}

1 - Preference for a 3D Tutor

2 - Gender Sensitivity of the 3D Tutor

3 - Preferred Learning objects

4 - Preferred Communication Devices

5 - Means of Communicating with the tutor

6 - Aggregation of the Web Resources

7 - Preferred Learning Path

8 - Communicating with the Tutor

* - Correlation is significant at the 0.05 level (2-tailed)

**_ Correlation is significant at the 0.01 level (2-tailed).

Table 14. LEARNING PATH PREFERENCE

\begin{tabular}{|l|l|l|l|}
\hline \multirow{2}{*}{ Degree } & \multicolumn{2}{|l|}{ Preference towards Sequential and Personalized Learning Path } & \multirow{2}{*}{ Total } \\
\cline { 2 - 4 } & Sequential Learning Path & Personalized Learning Path & \\
\hline $\begin{array}{l}\text { Under } \\
\text { Graduate }\end{array}$ & $\begin{array}{l}22(44.0) \\
(40.0)\end{array}$ & $\begin{array}{l}28(56.0) \\
(62.2)\end{array}$ & $\begin{array}{l}50(100.0) \\
(50.0)\end{array}$ \\
\hline $\begin{array}{l}\text { Post } \\
\text { Graduate }\end{array}$ & $\begin{array}{l}13(66.0) \\
(60.0)\end{array}$ & $(37.8)$ & $\begin{array}{l}50(100.0) \\
(50.0)\end{array}$ \\
\hline Total & $\begin{array}{l}55(55.0) \\
(100.0)\end{array}$ & $\begin{array}{l}45(45.0) \\
(100.0)\end{array}$ & $\begin{array}{l}100(100.0) \\
(100.0)\end{array}$ \\
\hline
\end{tabular}

Table XIII describes that majority (66.0) of the post graduate students preferred sequential path learning, because they are very fashioned in the chronological learning path and more than half $(56.0 \%)$ of the undergraduate students preferred to have a personalized path learning. 
Association (Chi Square Test)

Chi Square Value: 4.889

Degree Of Freedom: 1

Significance Value: 0.04

H0: There is no association between Degree of Study and their Preference towards Sequential or Personalized Learning Path.

H1: There is an association between Degree of Study and their Preference towards Sequential or Personalized Learning Path.

\section{CONCLUSION}

This paper provides an overview of the evolution of web and e-learning from web 1.0 to web 4.0. The attributes of each generation were introduced and discussed. Finally, it concludes that the web space develops rapidly and makes its progress into the future by including artificial intelligence to enable web to interact with human in highly intelligent manner.

From the analysis on the dataset collected, $\mathrm{H} 0$ can be rejected since the level of significance value is less than the 0.05 , and it could be concluded that there is an association between of the degree of study and preference of a learning path. So these attributes should be given preferences while designing / developing of elearning 3.0 applications.

\section{REFERENCES}

[1] http://en.wikipedia.org/wiki/Learning

[2] Richard M. Felder, Linda K. Silverman. (1988). Learning and Teaching Styles in Engineering Education. Engr. Education, 78(7), 674-681.

[3] Nancy Csapo, Roger Hayen. (2006). The Role of Learning Style in the Teaching Learning Process. Issues in Information Systems, 7(1).

[4] Jung, C.G. (1971). Psychological Types, Princeton University Press, Princeton, N.J. (Originally Published in 1921).

[5] Silverman, L.K. (1987). Global Learners: Our Forgotten Gifted Children, $7^{\text {Th }}$ World Conference on Gifted and Talented Children, Salt lake City, Ut.

[6] http://www.nwlink.com/donclark/hrd/styles/

[7] Ahmad Al-Khasawneh, Mohammad Khasawneh, Mohammad Bsoul, Sahar Idwan, Aykut Hamit Turan. (2013). Knowledge Management \& E-Learning: An International Journal, 2(4). http://www.tiresias.org/research/guidelines/e_learning.ht $\mathrm{m}$.

[8] Berners-Lee, T. (1995). Past, Present and Future, IEEE Computer, 29 (10), 69-77.

[9] http://novaspivack.typepad.com/nova_spivacks_weblog/ radar_networks/.

[10] O'Reilly, T. (2004). What is Web 2.0: Design patterns and business models for the next generation of software? http://www.oreillynet.com/pub/a/oreilly/tim/news/2005/ 09/30/what-is-web-20.html in March 2012.

[11] Deerwester, S., Dumais, S., Furnas, G., Landauer, T. in Harshman, R. (1990). Indexing by latent semantic analysis, Journal of the American society for information science, 41 (6), 391-407.

[12] http://mashable.com/category/augmented-reality/.

[13] Pascal Hitzler, Krzysztof Janowicz. (2103). Linked Data, Big Data, and the 4th Paradigm. Semantic Web, 4(3). 233-235.

[14] http://computer.howstuffworks.com/web-305.htm.

[15] http://gseacademic.harvard.edu/ hdul/.

[16] http://en.wikipedia.org/wiki/Wearable_computer.

[17] Alves da Silva, N., Morais da Costa, G., Prior, M. and Rogerson. (2011). The Evolution of E-learning Management Systems: An Ethical Approach, International Journal of Cyber Ethics in Education (IJCEE), 1(3):12-24.

[18] Meichel Blog. Meichel, F., Qu'est-ce que la cognition points de repères en sciences cognitives Qu'est-ce que la cognition - points de repères en sciences cognitive. Retrieved March 20, 2012 from http://florencemeichel.blogspot.com/2009/05/quest-ceque-la-cogntion-points-de.html. (English translation found at Wheeler, 2009b).

[19] Ron, Callari. (2009). Web 4.0, Trip Down the Rabbit Hole or Brave New World? http://www.zmogo.com/web/web-40trip-down-therabbit-hole-or-brave-new-world/.

[20] Dan, Farber. (2012). From semantic Web (3.0) to the WebOS (4.0). International Journal of Web \& Semantic Technology (IJWesT), 3(1). http://www.zdnet.com/blog/btl/from-semantic-web-30to-the-webos-40/4499/.

[21] Melanie Arthur. SPSS Companion for Research Methods, Revised Third Edition, Portland State University.

\section{AUTHORS AND THEIR CONTRIBUTIONS}

Maria Dominic received his Master's in Computer Science from Bharathidasan University, Trichy, India. He is currently an assistant professor in the Department of Computer Science at Sacred Heart College, Tirupattur, India. He is a research scholar in the field of e-Learning and Cloud Computing. This author contributed towards this paper in conception, design and acquisition of data.

Dr. Sagayaraj Francis is an associate professor in the Department of Computer Science and Engineering, Pondicherry Engineering College, Pondicherry, India. He specializes in Data Management, Data Modeling, Information Systems and e-Learning. This author contributed towards this paper in revising the manuscript critically for important intellectual content.

Anthony Philomenraj received his Master's in Computer Application from Thiruvalluvar University, Vellore. He is currently an assistant professor in the Department of MCA at Sacred Heart College, Tirupattur, India. He pursues his research in the field of e-Learning and Cloud Computing. This author contributes towards this paper in the analysis and interpretation of data. 